\title{
EFFECT OF INTERNAL AUDITOR INDEPENDENCE, AUDIT COMMITTEE AND INSTITUTIONAL OWNERSHIP TO THE INTERNAL CONTROL DISCLOSURE: A CASE STUDY CASE OF MANUFACTURING IDX COMPANY DURING PERIOD OF 2014-2016
}

\author{
Dimayanti Sukiswo Wahyu Helmy \\ Department of Accounting, Faculty of Economics and Business, University of Airlangga, \\ Surabaya, Indonesia \\ E-mail: wahyuhelmy@gmail.com
}

\begin{abstract}
The purpose of this research is to examine the effect of the independence of internal auditors, audit committee, and institutional ownership disclosure on internal control. Disclosure of internal control was measured with Internal Control Disclosure Index. The population of this research was the manufacturing firms listed in Indonesia Stock Exchange during 2014-2016. The samples in this research were taken using purposive sampling method and the number of the samples fulfilling the criteria was 69 . The mean value of the internal control disclosure is $58.69 \%$. The result of multiple regression analysis testing show that the independence of the internal auditor and institutional ownership has a significant positive effect on internal control disclosure. The audit committees do not have any effects on internal controls on disclosure.
\end{abstract}

\section{KEY WORDS}

Independence, internal auditors, audit committee, institutional ownership, internal control disclosure.

The executor of work is required to improve the efficiency and good performance in order to provide security for its investors. Thus, companies in the small and large scale must have an effective internal control system to support effective and efficient operation of the company. In the financial statements found some cheating scandal that could mislead users of financial statements.

The companies that have go public in Indonesia will reveal internal control at the company's annual report. Government Institutions Capital Market Supervisory Agency and Financial Institution (Bapepam-LK) has issued Regulation No. XK6.2012 on Obligation to Submit Report For issuers or Public Companies. The regulation is a refinement of the previous regulations which are intended to improve the quality of information disclosure in the annual report of the Issuer and public companies as a source of important information for shareholders and the public in making investment decisions.

PT Akasha Wira International Tbk, PT Kimia Farma Tbk, and PT Indofarma Tbk is a partial example of a manufacturing company who commit fraud in financial statements. Companies that have a long business process is manipulating the information content of profit by increasing sales and improving the value of inventory so that the profits presented higher than the actual situation (Dipanusa, 2013). According to Moeller (2009), everything was falsified, concealed, or made-up, is a form of fraud.

Effective internal control is the first step for the company to fight against fraud attacks. With the implementation of good internal control, enterprise management has a reasonable assurance that the company's goal has been achieved, the financial statements presented have been fair, as well as laws and regulations relating met (Boynton, 2006). Internal controls have become the basis for the effectiveness of their operational processes and corporate finance (Moeller, 2009).

The internal auditor is a business unit within the company that is required to maximize the disclosure of internal control to help companies avoid frauds that can make companies face risks are not expected. The independence of an auditor is the ability to act on the integrity and objectivity. Integrity is a moral principle that is impartial, honest, and suggested 
looking at the facts as they are. While objectivity is an attitude of impartiality in considering the facts, personal interest is not in fact facing (Barry, 2001).

In addition to internal auditors also needed as the audit committee of the supervisory committee for the audit committee has a great responsibility in preparing the audit, do ratrifikasi of the internal control system, and resolving disputes in accounting rules. The audit committee serves to provide views on issues relating to financial policy, accounting and internal control (Pancawati $\mathrm{H}, 2010$ ).

Means to create an effective internal control is also needed external parties participating in supervising the disclosure of internal control through institutional ownership. Institutional ownership is ownership by investors other than individual ownership and managerial ownership (Ujiyantho, 2007). The institutional shareholders will seek to improve oversight of the management of behavior in an effort to minimize the level of fraud that may arise which can decrease the value of the company. So with institutional ownership supervision carried out will be more effective and it effect on the broad disclosure of information by management.

Based on this background, the study entitled "Effect of Independence of Internal Auditors, the Audit Committee and Institutional Ownership to The Internal Control Disclosure on Manufacturing Company in Indonesia Stock Exchange Year 2014-2016.

Based on the description of the background of this research, the formulation of research problems that can be identified, as: Is the independence of the Internal Auditor, Audit Committee, and Institutional Ownership had effect on the Internal Control Disclosure?

\section{LITERATURE REVIEW AND HYPOTHESIS DEVELOPMENT}

Jensen and Meckling (1976) define agency theory as a contract in which one or more persons (as the principal) to request the other party (as the agent) to carry out a number of jobs in the name of principle which involves delegating some decision-making authority to the agent. Furthermore, Jensen and Meckling (1976) states that the agency problem can arise between the agent and the principal because of the tendency of one party for selfish and conflicts arise when multiple interests meet in a joint activity. The existence of a conflict of interest between prncipal and agent because of their different objectives encourage assymetry information. Jensen and Meckling (1976) stated that there are two types of assymetri information, namely: (1) Adverse Selection, for the agent to know more information than the principal, (2) Moral Hazard, occur because of the separation pincipal with the agent in managing the company, so the principal do not fully know about the running of the company.

To overcome this, we used the agency cost which consists of monitoring costs, bonding costs, and residual loss. Monitoring costs are costs incurred and borne by the principal to monitor the agent's behavior, which is to measure, observe, and control the behavior of the agent. Bonding costs are the costs borne by the agent to establish and adhere to a mechanism that ensures that the agent will act in the interests of the principals. Residual loss is a sacrifice in the form of principal welfare losses as a result of differences in the decision and the decision of the principal agent. The independence of the Internal Auditor and Internal Control Disclosure

The independence by IAI through SPAP (2001: 220): "This standard requires the auditor be independent, that is not easily influenced, because he was carrying out work in the public interest (differentiated in terms he practiced as an internal auditor)". The independence of the internal auditor is an independent attitude possessed by the internal auditor, so as to assess objectively and in the absence keterpihakan at an interest so as to suppress the disclosure of internal control.

Research results of Adani Yusrina (2013) and Rizal Alfian (2014) matches the positive influence the independence of the internal auditor of the internal control.

H1: The Independence of Internal Auditor Positively Influences to The Internal Control Disclosure.

Decision of the Capital Market Supervisory Board No. 29 / PM / 2004 is an audit 
committee formed by the board of directors for at least a member of the audit committee has the task of accounting education and management control of the company. The formation associated with the review of the company's internal control system, ensuring the quality of information disclosure and improve the effectiveness of the audit function.

Research results of Adani Yusrina (2013) and Febi Maulina (2014) found a significant influence on the results of internal control. Meanwhile, Amalia Wardhani (2010) get the results of the audit committee does not affect the internal controls were weak due to the organizational structure.

H2: Audit Committee Positively Influences to The Internal Control Disclosure.

Institutional ownership is ownership by financial institutions such as pension funds, mutual funds, insurance and other institutional ownership. The institutional shareholders will seek to improve oversight of the management of behavior in an effort to minimize problems that might arise agency (Jensen and Mecking, 1976).

Research results of Zulfikar, Rosiana. \& Nariah (2015) to get the positive significant effect on the disclosure of internal control. Meanwhile, Amalia D Latifah (2013) to get the institutional ownership has significant negative effect on the disclosure of internal control as the number of institutions that control policies lead to a less transparent disclosure.

H3: Institutional Ownership Positively Influences to The Internal Control Disclosure.

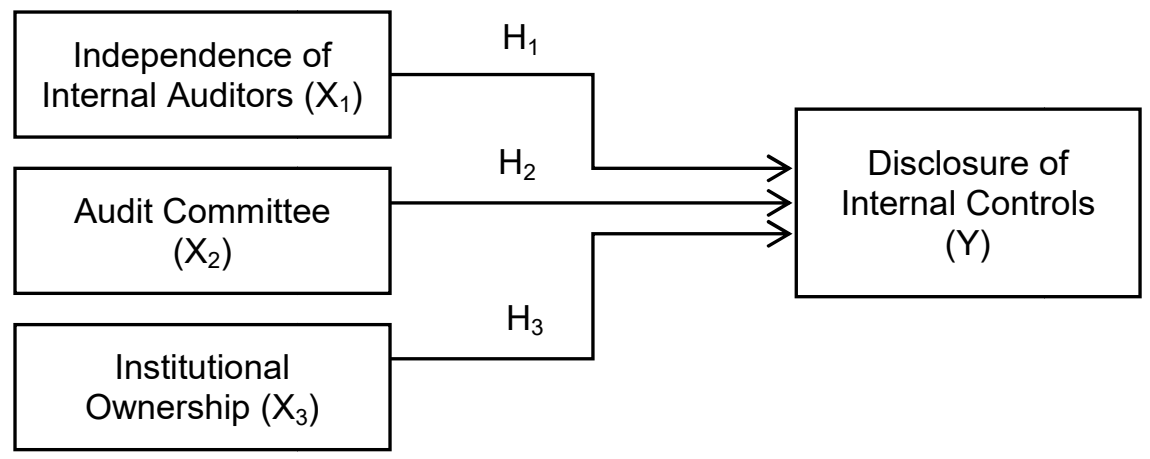

Figure 1 - Conceptual Framework

\section{METHODS OF RESEARCH}

The independence of the internal auditor is an internal auditor impartiality on an interest. Internal auditors in charge of controlling and ensuring policies and procedures are in accordance with the decision of the agency's top management to minimize conflict. independence of internal auditors in this study was measured by the number of internal auditors in the company.

$$
|A|=\sum \text { Auditor Internal in the Firm }
$$

Decision of the Capital Market Supervisory Board No. 29 / PM / 2004 is an audit committee formed by the board of directors to perform supervisory tasks of corporate management. Bank Indonesia Regulation No. 08.14.2006 states that at least one member of the audit committee have the skills of accounting education.

$$
\text { ACEDU }=\frac{\sum \text { Audit committee with accounting education background }}{\sum \text { Audit Committee in the firm }}
$$

Institutional ownership is ownership by institutional investors other than individual ownership and managerial ownership. Institutional ownership has a very important role in minimizing teradi agency conflict between shareholders and management. Institutional ownership is measured by the percentage of institutional ownership in the company.

$$
\mathrm{IO}=\frac{\sum \text { Common stock owned by institution }}{\sum \text { Share issued }} \times 100 \%
$$


Disclosure of internal control is the disclosure of information relating to the implementation of the company's internal control conducted disclosed in the company's annual report. This study uses the Internal Control Disclosure Index (ICDI) was measured using a dummy, by giving a value of 1 for each item disclosed, and the value 0 for items that are not disclosed, then divide the total items disclosed to the maximum value of all the items that amounted to 18 criteria. Disclosure items are arranged based on the regulation XK6.2012 on the Obligation to Submit Annual Reporting for Listed Company pubic.

$$
\mathrm{ICDIj}=\frac{\sum \mathrm{Xij}}{\sum \mathrm{nj}}
$$

Where:

ICDIj = Internal Control Disclosure Index company j;

$\mathrm{nj}=$ Number of items that must be disclosed company $\mathrm{nj}=18$ items;

$\mathrm{xij}=$ Dummy variable: 1 (if the item $\mathrm{i}$ disclosed); 0 (if the item $\mathrm{i}$ is not disclosed);

$0 \leq \mathrm{ICDlj} \leq 1$.

This study using purposive sampling method with the following criteria: (1) The manufacturing company which is consistently listed in the Indonesia Stock Exchange (BEI) during the period 2014-2016, (2) the Company issued its annual report for the period 20142016, (3) the Company provides data full on the variables used in the study. Samples obtained was number 69 the company's data.

Data used in the study of secondary data, the annual report of companies listed on the Indonesian Stock Exchange (BEI) in the period 2014-2016. Data obtained from the website of Indonesia Stock Exchange www.idx.co.id, is.pi

Descriptive statistics are directly related to data collection and measures of centralization of data and presentation of results of measures of central tendency of the data. Descriptive statistics were used to describe and provide a general overview of statistical research data for each variable in the study. Applications used for processing data in this research is the application of SPSS 20.0.

This study uses multiple regression analysis were used to measure the relationship between two or more variables and show the direction of the relationship between the dependent and independent variables (Ghozali, 2011). Prior to the calculation of multiple regression analysis to determine the effect of the independent variable on the dependent variable is bersasa together, it will be held the classical assumption test. Classic assumption test is done in order to meet the nature of regression estimation that is BLUES (Best Linear Unbiased Estimation). Classic assumption test consisting of: (1) Normality Test; (2) Test Multicolinearity; (3) Test Heteroskidastity; and (4) Test of autocorrelation. Regrsinya equation as follows:

$$
Y=\alpha+\beta 1 X 1+\beta 2 X 2++\beta 3 X 3+e
$$

Where:

$$
\begin{aligned}
& Y=\text { Disclosure of Internal Control; } \\
& \alpha=\text { constant; } \\
& \beta 1 \ldots \beta n=\text { Coefficient regression direction; } \\
& X 1=\text { Internal Auditor Independence; } \\
& X 2 \text { = the Audit Committee; } \\
& X 3 \text { = Institutional Ownership; } \\
& \text { e = Residual Error. }
\end{aligned}
$$

\section{RESULTS AND DISCUSSION}

Based on empirical testing, the result for the descriptive statistical information which includes the minimum value, maximum value, average value, and standard deviation. Descriptive statistics in Table 1 show the disclosure of internal control (PPI) has the lowest 
value of 0.2778 and 1.0000 highs. The lowest value disclosure of internal control is owned by PT. Light Wilmar Indonesia Tbk. occurred in 2014, while the greatest value disclosure of internal control is owned by PT. Indopoly Swakarsa Industry Tbk and PT. Tiga Pilar Sejahtera Food Tbk. occurred in 2016. The average PPI owned the entire company during the year of follow-up samples is 0.586957 with a standard deviation is 0.1887539 . It shows the distribution of PPI data has the degree of variation of $32.16 \%$ which indicates that the data obtained tend relatively homogeneous or have the same tendency among companies sampled.

Table 1 - Descriptive statistics

\begin{tabular}{|c|c|c|c|c|c|}
\hline $\mathrm{n} / \mathrm{n}$ & $\mathrm{N}$ & Minimum & maximum & mean & Std. deviation \\
\hline PPI & 69 & .2778 & 1.0000 & .586957 & .1887539 \\
IAI & 69 & 1 & 37 & $6: 30$ & 8026 \\
ACEDU & 69 & .0000 & 1.0000 & .502415 & .3494776 \\
INSOWN & 69 & .1400 & 74.0800 & 24.832743 & 19.2190622 \\
\hline
\end{tabular}

Source: Data processed, 2017.

The independence of the internal auditor has the lowest value (minimum) of 1 (one) and the highest (maximum) of 37 (thirty-seven). Based on the statistical processing, the value of the average (mean) of the number of internal auditors amounted to 6.30 and has stadard deviation of 8.026. From these data, the degree of variation of internal auditor independence can be seen at $127.39 \%$, which means that data is processed is heterogeneous in that the data relative to vary between companies.

Table 2 - Classic Assumption Test

(1) Normality Test

\begin{tabular}{|c|c|}
\hline & Residual unstandardized \\
\hline $\mathrm{N}$ & 69 \\
Kolmogorov-Smirnov Z & .552 \\
Asymp. Sig. (2-tailed) & .921 \\
\hline
\end{tabular}

(2) Test Results autocorrelation

\begin{tabular}{|c|c|c|c|c|}
\hline $\mathrm{dU}$ & $\mathrm{dW}$ & $4-\mathrm{dU}$ & RESULTS & CONCLUSION \\
\hline 1.7343 & 1,813 & 2.2657 & $\mathrm{dU} \leq \mathrm{dW} \leq 4-\mathrm{dU}$ & NO AUTOCORRELATION \\
\hline
\end{tabular}

(3) Multicollinearity Test

\begin{tabular}{|c|c|c|c|}
\hline \multirow{2}{*}{\multicolumn{2}{|c|}{ Model }} & \multicolumn{2}{|c|}{ collinearity Statistics } \\
\hline & & tolerance & VIF \\
\hline \multirow{4}{*}{1} & (Constant) & - & - \\
\hline & IAI & .753 & 1,328 \\
\hline & ACEDU & .926 & 1,080 \\
\hline & INSOWN & .954 & 1049 \\
\hline
\end{tabular}

(4) Heteroscedasticity Test

\begin{tabular}{|c|c|c|c|c|c|c|}
\hline \multicolumn{2}{|c}{ Model } & \multicolumn{2}{c|}{ Coefficients unstandardized } & standardized Coefficients & \multirow{2}{*}{$\mathrm{t}$} & \multirow{2}{*}{ Sig. } \\
\cline { 3 - 7 } & B & Std. Error & beta & .138 & .891 \\
\hline \multirow{4}{*}{1} & (Constant) & .031 & .227 & & -.750 & .456 \\
\cline { 2 - 7 } & IAI & -.001 & .002 & -.100 & 2,041 & .055 \\
\cline { 2 - 7 } & ACEDU & .064 & .031 & .246 & -1921 & .059 \\
\cline { 2 - 7 } & INSOWN & -.001 & .001 & -.229 & \\
\hline
\end{tabular}

Source: Data processed, 2017.

Accounting background audit committee has the lowest value (minimum) of 0 (zero) and highest value (maximum) of 1 (one). Based on the statistical processing, the value of the average (mean) of the number of internal auditors amounted 0,502415 and have stadard deviation of 0.3494776 . From these data, the degree of variation accounting educational backgrounds of the audit committee can be seen at $69.56 \%$, which means the data are homogeneous or have the same inclination relative data between companies.

Institutional ownership has the lowest value (minimum) at 0.1400 and the highest value 
(maximum) of 74.08. The lowest value indicated by PT Mayora Indah Tbk. (MYOR) in 2013 is $0.14 \%$ and the highest value indicated by PT Kabelindo Murni Tbk (KBLM) in 2013 which is $74.8 \%$. The average value (mean) of the sample firms of institutional ownership amounted to 24.832743 and has a standard deviation of 19.2190622. Institutional ownership has a degree of variation of $77.4 \%$, which means the data are homogeneous, i.e. have relatively similar trend among companies sampled.

Based on the classic assumption test by using the Kolmogorov-Smirnov test, DurbinWatson test, Run Test, and test Glejer note that the data used in this study the distribution data are normal and valid.

Table 3 - The Results of Multiple Linear Regression Model

\begin{tabular}{|c|c|c|c|c|c|c|}
\hline & \multirow{2}{*}{ Model } & \multicolumn{2}{|c|}{ Unstandardized Coefficients } & \multirow{2}{*}{$\begin{array}{c}\text { Standardized Coefficients } \\
\text { beta }\end{array}$} & \multirow{2}{*}{$\mathrm{t}$} & \multirow{2}{*}{ Sig. } \\
\hline & & $\mathrm{B}$ & Std. Error & & & \\
\hline \multirow{4}{*}{1} & (Constant) & -.179 & .401 & & -.447 & .656 \\
\hline & $\mid \mathrm{Al}$ & .011 & .003 & .482 & 4,269 & .000 \\
\hline & ACEDU & .071 & .055 & .131 & 1,289 & .202 \\
\hline & INSOWN & .002 & .001 & .210 & 2,099 & .040 \\
\hline
\end{tabular}

Coefficient Determination Test

\begin{tabular}{|c|c|c|c|c|c|}
\hline Model & R & R Square & Adjusted R Square & Std. Error of the Estimate & Durbin-Watson \\
\hline 1 & $.622^{\mathrm{a}}$ & .387 & .349 & .1523145 & 1.813 \\
\hline
\end{tabular}

Source: Data processed, 2017.

Based on the table, equation influence the independence of the internal auditor, the audit committee, and institutional ownership on the disclosure of internal control, sebgai follows:

$$
P P I=-0,179+0,011 \mathrm{IAI}+0,071 \text { ACEDU + 0,002 INSOWN + error }
$$

Based on Table 3, the value of Adjusted R Square of 0.349 (34.9\%). This suggests that the independent variables used in this study may explain the disclosure of internal control (PPI) amounted to $34.9 \%$, while the remaining $65.1 \%$ influenced by other variables that are not used in this study.

Hypothesis 1: The independence of the Internal Auditor Positively Influence to the Internal Control Disclosure.

The hypothesis of this study aimed to examine the effect of the internal auditor independendensi (IAI) on the disclosure of internal control (PPI). From the regression results are presented Table 3 it can be concluded that the independence of the internal auditor (IAI) effect on the disclosure of internal control. This can be seen by the significant value of count (Sig.) of 0.000 . This demonstrates the significant value count <error rate (0.05). This marks the independence of the internal auditor significant effect on the disclosure of internal control at the $95 \%$ confidence level.

Number of auditors can increase independence with increasingly diverse findings and opinions by internal auditors can streamline management measures in the disclosure of information. Based on the calculated value and the significance of the regression coefficients to see the effect of the internal auditor independence on the disclosure of internal control, it can be concluded that the independence of the internal auditor has a positive effect on the disclosure of internal control and proved significant.

Hypothesis 2: Audit Committee Positively Influence to The Internal Control Disclosure.

The hypothesis of this study aimed to examine the effect of the audit committee (ACEDU) on the disclosure of internal control (PPI). From the regression results are presented Table 3 it can be concluded that the audit committee accounting background but not significant effect on the disclosure of internal control. This can be seen by siginifikansi count (Sig.) Of 0.202. This demonstrates the significant value count> error rate (0.05). This marks the audit committee accounting background but not significant effect on the disclosure of internal control. 
Background regression coefficient value accounting for 0,071 audit committee concluded the audit committee accounting background can increase the Disclosure of Internal Control (PPI) and the positive impact on the PPI. The audit committee accounting background has a high competence in reviewing the company's internal control system and ensures the quality of information disclosure, no significant results occurred because the educational background of accounting audit committee can not give a guarantee for the disclosure of internal control is effective or ineffective. The audit committee seeks accounting background to perform its role as a corporate function corresponding commitment and experience. Based on the calculated value and the significance of the regression coefficients to see the effect of an accounting background audit committee on disclosure of internal control, it can be concluded that audit committees effect but not significant to the disclosure of internal control.

Hypothesis 3: Institutional Ownership Positively Influence to The Internal Control Disclosure.

The hypothesis of this study aimed to examine the effect of institutional ownership (INSOWN) on the disclosure of internal control (PPI). From the regression results are presented Table 3 it can be concluded that institutional ownership (INSOWN) effect on the disclosure of internal control. This can be seen by the significant value of count (Sig.) Of 0,040 . This demonstrates the significant value count <error rate $(0.05)$. This indicates institutional ownership has a significant effect on the disclosure of internal control at the $95 \%$ confidence level.

Institutional ownership regression coefficient of 0.002 can be concluded institutional ownership can increase the Disclosure of Internal Control (PPI) and the positive impact on the PPI. Increasing the institutional share holders institutions'll attempt to improve oversight of the management of behavior in an effort to minimize agency problems that may arise. Based on the calculated value and the significance of the regression coefficients to see the influence of institutional ownership on the disclosure of internal control, it can be concluded that institutional ownership affects the disclosure of internal control and proved significant.

\section{CONCLUSION}

This study examines the effect of the independence of the internal auditor, the audit committee, and institutional ownership on the disclosure of internal control. The following are the conclusions of this study:

- The test results and analysis indicate that the independence of the internal auditor proxied by the number of internal auditors affect the significance level of $5 \%$;

- The test results and analysis indicate that the audit committee is proxied by the educational background of the audit committee of accounting does not affect the significance level of $5 \%$;

- The test results and the analysis show that institutional ownership proxied by the percentage of institutional ownership affects the significance level of $5 \%$.

\section{REFERENCES}

1. Adani, Yusrina. (2013). Influence of Internal Auditor Independence and Audit Comittee of Internal Control (Research in Banking Bandung). Journal of Economic. Bandung. UNIKOM.

2. Alfian, Rizal. (2013). Pengaruh Efektivitas Fungsi Audit Internal Terhadap Pengungkapan Kelemahan Pengendalian Internal. Jurnal Akuntansi. Universitas Pendidikan Indonesia.

3. Anshori, Mushlich dan Sri Iswati, 2009. Buku Ajar Metodologi Penelitian Kuantitatif. Surabaya: Fakultas Ekonomi Universitas Airlangga.

4. Boynton, W.C. \& R.N. Johnson. 2006. Modern Auditing: Assurance Services and the Integrity of Financial Reporting, $8^{\text {th }}$ Edition. New York: John Wiley \& Sons. Inc. 
5. Dipanusa, B. A. 2013. Pengaruh Investment Opportunity Set (IOS), Komisaris Independen, Kepemilikan Manajerial, dan Kepemilikan Institusional Terhadap Kualitas Laba.

6. Ghozali, Imam. 2011. Aplikasi Analisis Multivariate Dengan Program Ibm SPSS 19. Semarang: Badan Penerbit Universitas Diponegoro.

7. Heliodoro, Paula Alexandra, F.A. Carreira, \& M.M. Lopes. 2015. The Change of Auditor: Portuguese Case. Spanish Accounting Review.

8. Ikatan Akuntan Indonesia. 2011. Standar Profesional Akuntan Publik. Jakarta: Salemba Empat.

9. Jensen, Michael C, \& Meckling, William H. 1976. Theory of The Firm: Managerial Behavior, Agency Costs and Ownership Structure. Journal of Financial Economics 3(4): 305-360.

10. Latifah, Amalia. (2014). Pengaruh Karakteristik Perusahaan terhadap Internal Control Disclosure. Jurnal Akuntansi. Semarang.

11. Mahantara, AA. 2013. Faktor-faktor yang Mempengaruhi Pergantian Kantor Akuntan Publik pada Perusahaan yang Terdaftar di Bursa Efek Indonesia. E-Journal Ekonomi dan Bisnis Universitas Udayana 2(10).

12. Maulina, Febi. (2014). Efektivitas Komite Audit dalam Sudut Pandang Auditor Internal pada PT Semen Indonesia (Persero) Tbk. Jurnal Akuntansi. UNAIR. Surabaya

13. Menteri Keuangan RI, 2008, Peraturan Menteri Keuangan Nomor: 17/PMK.01/2008 Jasa Akuntan Publik. 5 Januari 2008.

14. Moeller, R. R. 2009. Brink's modern internal auditing: A common body of knowledge. John Wiley \& Sons.

15. Moore, Don A, Tetlock, Philip E, Tanlu, Lloyd, \& Bazerman, Max H. 2006. Conflict of Interest and The Case of Auditor Independence: Moral Seduction and Strategic Issue Cycling. Academy of Management Review 31(1): 10-29.

16. Pancawati, Hardiningsih. 2010. Pengaruh Independensi, Corporate Governance, dan Kualitas Audit Terhadap Integritas Laporan Keuangan. Kajian Akuntansi, Pebruari 2010 Vol 2 No. 1 Hal $61-76$.

17. Peraturan Standar Akuntansi Keuangan No. 1 (Revisi 2013) Penyajian Laporan Keuangan. Dewan Standar Akuntansi Keuangan-lkatan Akuntan Indonesia. Jakarta.

18. Scott, William R. 2003. Financial Accounting Theory (Third Edition ed.). USA: Prentice Hall.

19. Standar Umum SA Seksi 220 Independensi

20. Ujiyantho, Arif Muh. dan B.A. Pramuka. (2007). Mekanisme Corporate Governance, Manajemen Laba dan Kinerja Keuangan. Simposium Nasional Akuntansi X, Makasar, 26-28 Juli

21. Wardhani, Amalia. (2011). Evaluasi Peranan Komite Audit pada Sistem Pengendalian Internal Penjualan pada Klinik Kecantikan London Beauty Centre. Jurnal Akuntansi. Surabaya.

22. Zulfikar, R., Rosiana, R., \& Nariah, R. (2015). Corporate Governance dan Pengungkapan Pengendalian Internal. Vol.1 No. 2. 